\title{
STRATEGI PENGEMBANGAN EVEN DI MUSEUM UNTUK MENINGKATANKAN KUNJUNGAN WISATAWAN KE MUSEUM R.A KARTINI REMBANG
}

Muhammad Nilzam Aly

NIDN.0020099002

Email: nilzamaly@vokasi.unair.ac.id

Program Studi D3 Kepariwisataan/Bina Wisata, Fakultas Vokasi, Universitas Airlangga

\begin{abstract}
This research discusses the development strategy undertaken by the manager of R.A Kartini Museum especially related to the implementation of an event held in R.A Kartini Museum, Rembang Regency. This research is a qualitative descriptive research supported by the use of quantitative data such as the number of tourist visits. The results of research advised that the R.A Kartini Museum manager must consider the expectations and necessary of the visitors with the main purpose of the museum. The educational missions need more attention by the manager of R.A Kartini Museum one of them with the implementation of the event. So hope the museum is not like a storehouse of historical objects but can also be a media trip and have fun that reaches all levels of society
\end{abstract}

Keywords: R.A Kartini Museum Rembang, event, tourism

\section{PENDAHULUAN}

Sejak awal didirikan, secara umum museum dikelola utamanya untuk menyampaikan pesan-pesan edukasi yang di dalamnya meliputi kegiatan penelitian sekaligus penyajian benda-benda museum (Unesco, 2012). Secara tradisional museum dipandang sebagai tempat untuk melihat masa lalu, museum juga memiliki peran dalam menyediakan masyarakat dengan kesempatan untuk memahami masa kini dan menginformasikan masa depan (Stylianou-Lambert, Boukas, \& Christodoulou-Yerali, 2014).

Perkembangan saat ini menunjukkan bahwa museum telah memperoleh peran publik yang jauh lebih luas daripada periodeperiode terdahulu. Fakta ini menjelaskan bahwa museum pada konteks sekarang harus mengoptimalisasi potensi waktu luang yang dimiliki oleh public. Dasar tersebut dapat digunakan agar museum dapat mengartikulasikan dan memanfaatkan faktor rekreasi sebagai fungsi tambahan dalam misinya untuk melayani kebutuhan edukasi masyarakat kontemporer.

Tuntutan sekarang museum ditempatkan sebagai organisasi publik yang memerlukan keberlanjutan sosial, lingkungan dan ekonomi (Ambrose dan Paine, 2012;Camarero \& Garrido, 2012; Pencarelli, Cerquetti, \& Splendiani, 2016). Keberlanjutan ini bias dilihat melalui peningkatan keterlibatan dalam skala yang lebih luas dan volume pengunjung yang lebih besar. Hal ini yang selanjutnya bisa berkontribusi positif terhadap museum, baik dalam hal kunjungan, keterlibatan berkelanjutan melalui keanggotaan (kaderisasi), kunjungan berikutnya dan 
rekomendasi (Stylianou-Lambert et al., 2014).

Perkembangan ini yang selanjutnya bisa ditangkap oleh banyak pengelola museum di Indonesia. Selain menampilkan benda-benda bersejarah, banyak dari pengelola museum yang memberikan atraksi tambahan semisal city tour yang dikelola oleh House of Sampoerna di Surabaya. Penyelenggaraan even tingkat internasional diadakan pada kurun waktu 2016 dan 2017 seperti Pameran Arsitektur dan Tata Kota Prancis-Indonesia dan Indonesia Heroic Corner Surabaya. Seluruh penyelenggaraan even melibatkan banyak pihak seperti berbagai komunitas dan akademisi (Observasi, 2017). Dengan mengundang komponen masyarakat ke dalam suatu acara di museum dapat menimbulkan minat dan perhatian mereka untuk museum (Cole, 2008).

Manajemen atraksi dikembangkan sedemikian rupa oleh Museum Ullen Sentalu di Yogyakarta dengan menonjolkan kebudayaan Jawa. Museum ini juga rutin menyelenggarakan even internasional seperti International Mask Festival pada tahun 2016. Di Inggris, tepatnya di NorthEast of England diselenggarakan sebuah program bercerita terbesar. Proyek ini menggunakan museum dan galeri untuk menginspirasi orang-orang dalam membuat cerita mereka sendiri. Cerita yang telah jadi selanjutnya dijadikan sebagai koleksi museum yang relevan dan disiarkan secara daring serta pada acara-acara khusus (Nielsen, 2017).

Interaksi antara pengelola dengan pihak luar terkait manajemen atraksi even sangat diperlukan untuk meluaskan domain kerja sekaligus juga bisa menjadi sarana pemasaran yang sangat strategis. Sifat atraksi yang interaktif dengan pengunjung mampu dikelola sedemikian rupa oleh pengelola Museum Batik Danar Hadi. Pengunjung diberikan kesempatan untuk ikut membatik. Selain itu kolaborasi dengan dunia internasional juga dilakukan oleh pengelola Museum Batik Danar Hadi dengan Jim Thompson Art Center dari Thailand. Mereka mengadakan semacam pameran seni batik dan fashion show (Observasi, 2017).

Kabupaten Rembang memiliki potensi yang sangat besar di bidang kepariwisataan. Sejak satu tahun terakhir sektor pariwisata di Kabupaten Rembang berkembang pesat (jawapos.com, diakses 11 Januari 2018). Sayangnya konsentrasi pengembangan kepariwisataan oleh stakeholders lebih difokuskan pada kawasan pesisir pantai utara. Hal ini dapat dilihat dari beberapa objek wisata pantai yang tergolong baru seperti Pantai Karang Jahe, Pantai Caruban, Pantai Balongan, dan sebagainya.

Berdasarkan data Dinas Kebudayaan, Pariwisata, Pemuda, dan Olahraga (Dinbudparpora), tingkat kunjungan ke Museum R.A Kartini mengalami fluktuasi. Pada tahun 2010 jumlah pengunjung tercatat sebesar 4.562. Pada tahun 2011 mengalami penurunan menjadi 3.027 pengunjung. Sedangkan pada tahun 2012 mengalami kenaikan cukup signifikan lebih dari $100 \%$ sebesar 8.384 pengunjung dan terakhir pada tahun 2013 mengalami penurunan menjadi 6.372 pengunjung. Fluktuasi tingkat kunjungan ini semakin terlihat jelas berdasarkan data-data pada periode sebelumnya (RKPD, 2014).

Berdasarkan penjelasan yang telah disampaikan, maka rumusan masalah yang dikaji dalam penelitian ini berkaitan dengan bagaimana strategi pengembangan even di Museum R.A Kartini sebagai upaya untuk 
meningkatkan jumlah kunjungan yang telah dilakukan oleh para pemangku kepentingan di Kabupaten Rembang.

\section{LITERATURE REVIEW}

Menurut Peraturan Pemerintah Republik Indonesia Nomor 66 Tahun 2015 museum adalah lembaga yang berfungsi melindungi, mengembangkan, memanfaatkan koleksi, dan mengomunikasikannya kepada masyarakat. Sedangkan menurut International Council of Museum (ICOM) yang telah menyelenggarakan semacam konferensi ilmih ke-11 pada tahun 1974 (Sutarga, 1998), museum adalah sebuah lembaga yang bersifat tetap, tidak mencari keuntungan, melayani masyarakat dan perkembangannya, terbuka untuk umum, memperoleh, merawat, menghubungkan dan memamerkan artefak-artefak perihal jati diri manusia dan lingkungannya untuk tujuan studi, pendidikan dan rekreasi. Sebenarnya Sutarga (1998) telah menyampaikan secara tegas bahwa fungsi museum pasti mengalami perubahan setiap periode. Berdasarkan hal ini, dalam perkembangannya museum tidak hanya berfungsi sebagai pusat edukasi saja. Hal ini yang menyebabkan ICOM merilis semacam buku panduan terbaru tentang pengelolaan museum pada tahun 2004. Menurut ICOM (2004) setidaknya ada beberapa fungsi museum; fungsi edukasi; fungsi hiburan; fungsi komunikasi. Museum juga telah menentukan semacam tarif masuk untuk memperoleh pendapatan yang diperoleh dari pengunjung sehingga menjadi bagian penting berkaitan dengan pengelolaan keuangan museum (Lindqvist, 2012)

Menurut Lord dalam Subhiksu dan Rai Utama (2018) berkaitan dengan museum terdapat beberapa metode pengelolaan antara lain: (1) peran pelaksanaan, (2) manajemen koleksi (3) manajemen program umum, (4) manajemen akomodasi dan (5) manajemen keuangan. Pratminingsih dan Soedijati dalam Subhiksu dan Rai Utama (2018) menyatakan bahwa museum tidak hanya berupa tempat untuk memajang bendabenda yang dilestarikan namun sebenarnya menyediakan informasi tentang banyak hal berkaitan dengan kebesaran sebuah budaya masa lalu, mendidik, dan menghibur para pengunjung. Hasil penelitian yang dilakukan oleh Pratminingsih dan Soedjati menunjukkan bahwa untuk meningkatkan jumlah kunjungan, pengelola museum harus mampu meningkatkan kualitas layanan khususnya faktor daya tanggap dan empati terhadap para konsumennya.

Strategi pemasaran bisa dilakukan oleh pengelola museum dengan membuat dan mengemas suatu even. Even yang dibuat tetap mengedepankan aspek pendidikan dan hiburan yang seimbang sebagai bagian dari misi utama museum (Barron \& Leask, 2017). Penyelenggaraan even di museum lebih mudah diakses oleh khalayak luas -dan khususnya bagi pengunjung yang biasanya tidak tertarik pada museum tradisional-pengelola dan berbagai komponen masyarakat menciptakan banyak acara berskala besar dan pameran retrospektif pada topik-topik tertentu (Camarero, 2009). Apalagi saat ini generasi milenEal atau generasi $\mathrm{Y}$ juga memiliki karakter yang berbeda. Oleh karena itu, untuk meningkat-kan aspek acara ini, manajemen mungkin ingin mempertimbangkan penyediaan kegiatan untuk mendorong eksplorasi galeri, mungkin melalui penyediaan tempat berswafoto yang direncanakan di tempattempat yang tenang di dalam galeri untuk 
mendorong arus pengunjung ke ruangruang tertentu (Barron \& Leask, 2017)

\section{METODE PENELITIAN}

Penelitian ini berlokasi di Kabupaten Rembang dengan fokus kajian tentang strategi pengembangan even yang dilakukan oleh pengelola Museum R.A Kartini berkaitan dengan upaya peningkatan jumlah kunjungan. Penelitian ini menggunakan metode penelitian kualitatif dengan pendekatan deskriptif. Metode ini dipilih karena dalam penelitian ini lebih banyak menggambarkan kondisi realitas pada locus dan fokus penelitian yang diamati sesuai dengan fenomena yang ada. Penelitian deskriptif bertujuan untuk memberikan gambaran yang lebih detail mengenai gejala atau fenomena sosial tertentu, yaitu pengem-bangan Museum Kartini Rembang yang dilakukan oleh stakeholder melalui penyelenggaraan even sebagai upaya untuk peningkatan jumlah kunjungan.

Metode pengumpulan data dalam penelitian kualitatif ini dilakukan dengan menggunakan teknik:

1. Wawancara

Wawancara merupakan salah satu metode pembuktian atas suatu informasi atau keterangan yang diperoleh sebelumnya. Teknik wawancara yang digunakan dalam penelitian kualitatif adalah wawancara mendalam (indepth interview) dengan melakukan wawancara dengan satu per satu informan. Proses untuk mendapatkan informasi dari informan. (Manzilati, 2017). Beberapa narasumber yang berhasil ditemui adalah Bapak Muttaqien selaku pengelola Museum R.A Kartini sekaligus sebagai Kepala Bidang Kebudayaan Dinbudparpora Kabupaten Rembang. Selanjutnya adalah Nugraeni
Saputri N.H selaku pemandu wisata di Museum R.A Kartini. Selain itu wawancara dilakukan juga dengan beberapa wisatawan yang pernah mengunjungi Museum R.A Kartini.

2. Observasi

Observasi dilakukan dengan melakukan pengamatan dan kunjungan ke Museum R.A Kartini. Peneliti melakukan kunjungan bertujuan riset sekaligus untuk melakukan kegiatan wisata.

3. Studi Dokumentasi

Studi dokumentasi sebenarnya teknik pengumpulan data dengan menghimpun dan menganalisis dokumen-dokumen, baik dokumen tertulis, gambar, hasil karya, maupun elektronik. Dokumen yang telah diperoleh kemudian dianalisis (diurai), dibandingkan dan dipadukan (sintesis) membentuk satu hasil kajian yang sistematis, padu dan utuh. Studi dokumenter tidak sekedar mengumpulkan dan menuliskan atau melaporkan dalam bentuk kutipan-kutipan tentang sejumlah dokumen yang dilaporkan dalam penelitian adalah hasil analisis terhadap dokumendokumen tersebut. Studi dokumen merupakan pelengkap dari penggunaan metode observasi dan wawancara dalam penelitian kualitatif. Bahkan kredibilitas hasil penelitian kualitatif ini akan semakin tinggi jika melibatkan atau menggunakan studi dokumen ini karena berfungsi untuk menentukan focus penelitian (Yusuf, 2014). Beberapa dokumentasi telah didapatkan peneliti dari terbitan surat kabar online dan cetak, dokumen dari pemerintah Kabupaten Rembang berikut SKPD-nya, dan hasil dokumentasi pribadi.

\section{HASIL DAN PEMBAHASAN}

Pembahasan dalam artikel ini meliputi gambaran umum mengenai 
karakteristik objek kajian yaitu Museum R.A Kartini Rembang serta berbagai upaya dan strategi penyelenggaraan even yang telah dilakukan oleh pemangku kepentingan (stakeholders) termasuk evaluasi yang dilakukan melalui sudut pandang akademisi sehingga bisa menjadi bahan masukan untuk pengem-bangan museum ke arah yang lebih baik.

\section{Gambaran Umum Museum R.A Kartini Rembang}

Penambahan kata 'Rembang' di belakang Museum R.A. Kartini bertujuan untuk membedakan dengan Museum R.A. Kartini yang berada di Kabupaten Jepara. Oleh karena memang ada dua museum tentang R.A. Kartini. Museum R.A. Kartini di Kabupaten Jepara lebih banyak berkisah tentang masa sebelum dia menikah. Sementara itu Museum R.A Kartini Rembang lebih berkisah tentang kehidupan R.A Kartini setelah menjadi istri dari Bupati Rembang saat itu KRM Adipati Ario Djojoadhiningrat (1889-1912) sehingga Museum R.A. Kartini ini umumnya juga dikenal dengan nama Museum Kamar Pengabdian R.A. Kartini.

Museum R.A Kartini Rembang sekarang berada satu kawasan dengan Kantor Dinas Kebudayaan, Pariwisata, Pemuda dan Olahraga (Dinbudparpora) Kabupaten Rembang, Jawa Tengah. Gedung museum ini berisi 133 koleksi yang berasal dari peninggalan R.A Kartini dan keluarga Bupati Rembang, KRM Adipati Ario Djojoadhiningrat dan sempat menjadi kantor Bupati Rembang sampai tahun 1964. Di seberang timur bangunan museum terdapat bangunan sekolah yang pernah dijadikan tempat mengajar oleh R.A Kartini. Museum R.A Kartini tidak hanya koleksi di dalamnya yang bersejarah, melainkan bangunannya.

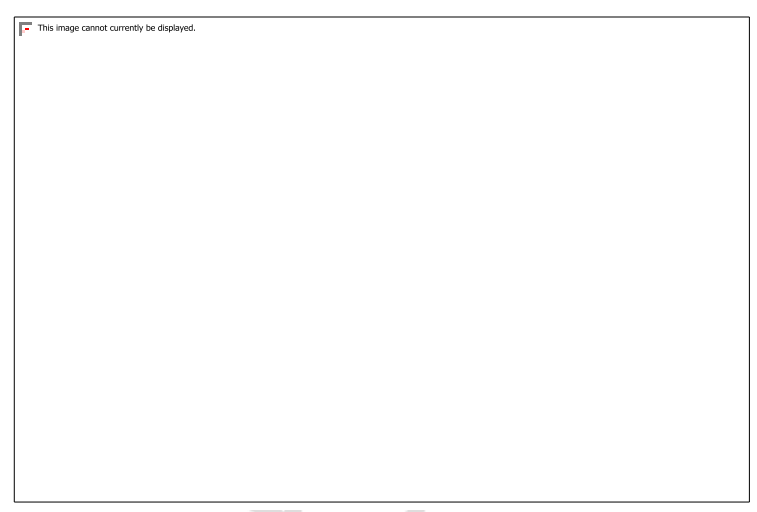

Gambar 1. Gapura Pendopo Museum R.A Kartini

Sumber: Koleksi pribadi

Setelah melewati pintu masuk yang bercorak klasik bercat hijau dengan tiang yang cukup besar bergaya Eropa, pengunjung akan berada di ruang tengah. Ruang tengah ini berisi relief R.A. Kartini dan KRM Adipati Ario Djojoadhiningrat, bendera Sang Saka Merah Putih dan bendera Kabupaten Rembang, silsilah R.A. Kartini dan KRM Adipati Ario Djojoadhiningrat. Lalu, di bagian kiri dan kanan bangunan terdapat ruang penyajian koleksi yang terbagi beberapa ruangan:

1. Ruang Pengabdian R.A. Kartini

Di dalam ruangan ini terdapat kamar tidur R.A. Kartini yang terbuat dari kayu jati berukir, bernuansa klasik, serta meja kecil yang sering digunakan oleh R.A. Kartini di dalam kamar tidur tersebut. Ruangan ini pula yang digunakan R.A. Kartini untuk melakukan aktivitas menulis buah pikiran dan ide-idenya, dan melahirkan putra satu-satunya sampai dia wafat.

2. Ruang Kamar Tidur KRM Adipati Ario Djojoadhiningrat

Ruang ini berisi sejumlah foto kenangan Bupati Rembang KRM Adipati 
Ario Djojoadhiningrat, baik saat mudanya maupun setelah menjadi Bupati Rembang. Ruangan ini juga merupakan kamar peraduan Sang Bupati.

\section{Ruang Penyimpanan Koleksi}

Ruang ini menyimpan sejumlah foto

R.A. Kartini bersama saudara-saudaranya sewaktu masih tinggal di Jepara, maupun peristiwa-peristiwa yang terkait dengan R.A. Kartini.

\section{Ruang Dapur}

Pada ruangan ini terdapat sejumlah alat-alat memasak atau yang berhubungan dengan dapur, dan satu set meja kursi untuk makan keluarga yang terlihat antik. Di ruangan ini juga terlihat ada lampu gantung antik dan kolom bergaya Eropa.

\section{Ruang Batik}

Ruang ini berisi pajangan lukisan hasil karya R.A. Kartini dan beberapa motif batik yang pernah dimiliki oleh R.A. Kartini maupun keluarganya.

\section{Ruang Keluarga}

Pada ruang ini terdapat satu set meja kursi antik yang dulu pernah digunakan oleh R.A. Kartini dan keluarga serta beberapa foto. Selain itu juga ada lemari kaca untuk memajang pusaka milik keluarga. Di sini juga terdapat ruang belajar Kartini.

7. Ruang Habis Gelap Terbitlah Terang Ruang koleksi ini berisi pajangan tulisan-tulisan yang pernah dibuat oleh R.A. Kartini. Tata ruang di sini sesuai dengan nama ruangannya. Tulisannya berwarna putih, dengan latarnya berwarna hitam.

8. Ruang Koleksi Buku

Pada ruang ini terdapat sejumlah koleksi surat-surat dan buku yang berhubungan dengan R.A. Kartini. Suratsurat ditempel pada dinding dengan dilapisi kaca yang diberi lampu. Buku-bukunya ditaruh pada ruang kaca yang diletakkan di tengah-tengah ruangan ini.

Berdasarkan data pada tabel 1 ada beberapa kesimpulan yang bisa dicermati. Pertama, terdapat tiga jenis objek wisata yang menggunakan nama R.A Kartini. Berdasarkan hal ini bisa dikaji lebih lanjut bahwa Kabupaten Rembang berupaya untuk menegaskan posisinya sebagai kota yang identik dengan R.A Kartini. Hal ini yang seharusnya bisa dikembangkan lebih jauh lagi bahwa tanggal 21 April sebagai hari lahir R.A Kartini bisa diadakan even yang berskala internasional atau lebih besar di Kabupaten Rembang, khususnya di kawasan museum R.A Kartini. Kabupaten Jepara sendiri sebagai kota kelahiran R.A Kartini hanya terdapat dua objek wisata yang menggunakan nama R.A Kartini, Museum R.A Kartini dan Pantai Kartini.

Tabel 1. Jumlah Kunjungan ke Objek Wisata Tahun 2011-2013 di Kabupaten Rembang

\begin{tabular}{|c|c|c|c|c|}
\hline No & $\begin{array}{c}\text { Nama Objek } \\
\text { Wisata }\end{array}$ & 2011 & 2012 & 2013 \\
\hline 1 & $\begin{array}{l}\text { Taman Ria } \\
\text { Pantai Kartini }\end{array}$ & 391.341 & 1.182 .313 & 2.272.241 \\
\hline 2 & $\begin{array}{l}\text { Museum } \\
\text { Kartini }\end{array}$ & 3.027 & 7.444 & 6.372 \\
\hline 3 & $\begin{array}{l}\text { Wana Wisata } \\
\text { Mantingan }\end{array}$ & 21.851 & 10.388 & 7.546 \\
\hline 4 & \begin{tabular}{|ll} 
Makam & R.A \\
Kartini & \\
\end{tabular} & 16.452 & 22.689 & 58.565 \\
\hline \multicolumn{2}{|c|}{ Total } & 432.671 & 1.223 .774 & 2.344.724 \\
\hline
\end{tabular}

Sumber : Dinbudparpora Rembang

Kedua, jumlah kunjungan tertinggi masih ditempati oleh Taman Ria Pantai (TRP) Kartini dan selalu mengalami kenaikan jumlah kunjungan tiap tahun secara signifikan. Hal ini menunjukkan bahwa wisata bahari masih menjadi atraksi utama di Kabupaten Rembang. TRP Kartini selain menawarkan wisata pantai juga terdapat beberapa atraksi yang menarik 
minat wisatawan seperti kebun binatang mini, wahana permainan, dan sebagainya. TRP Kartini juga semakin ramai ketika diadakan puncak acara syawalan pada hari ke tujuh setelah hari raya Idul Fitri.

Ketiga, dari keempat objek wisata tersebut jumlah kunjungan terendah per tahun berada di Museum R.A Kartini dan angkanya sangat fluktuatif. Terdapat beberapa kemungkinan yang bisa dilihat berdasar data tersebut. Diantaranya museum sebagai media edukasi kurang diminati oleh calon wisatawan yang datang ke Kabupaten Rembang, kemampuan promosi stakeholders yang masih belum maksimal, rendahnya kemampuan administrasi dalam melakukan pencatatan jumlah pengunjung.

Terkait yang terakhir ini terdapat fakta bahwa dalam tabel data tersebut pengunjung yang tidak membayar retribusi tidak terdata. Pengunjung yang tidak membayar ini berjumlah cukup besar yaitu $50 \%$ per tahunnya (Leksono, 2017). Sekadar tambahan bahwa besaran retribusi yang dibebankan kepada setiap wisatawan untuk masuk ke Museum R.A Kartini hanya Rp. 2000,- sesuai dengan Peraturan Daerah Kabupaten Rembang Nomor 13 Tahun 2011 Tentang Retribusi Jasa Usaha. Sebenarnya saat wisatawan masuk, petugas sudah menyiapkan buku tamu yang berisi tanggal kunjungan, nama, dan asal pengunjung untuk diisi oleh wisatawan. Sayangnya hasil rekapitulasi yang dilaporkan dan dipublikasikan kepada masyarakat sangat sederhana dan terkesan seadanya.

\section{Strategi Pengembangan Even}

Jumlah kunjungan wisatawan pada tahun 2014 dan 2015 harusnya mengalami peningkatan karena jumlah kontribusi dari hasil pengelolaan Museum R.A Kartini juga meningkat dari Rp.10.000.000,- pada tahun 2014 menjadi Rp. 12.000.000,- pada tahun 2015 (http://mataairradio.com, diakses pada 11 Januari 2018). Pendapatan ini sangat tidak sebanding dengan biaya pengelolaan museum yang sebesar Rp.100.000.000,pada tahun 2015 (RKPD, 2014). Berdasarkan RKPD tahun 2014 kegiatan Kartinian diselenggarakan di Museum R.A Kartini pada tahun 2015 dengan berbagai macam festival. Target sasarannya adalah generasi muda, pelajar,dan anak - anak dan pembiayaan kegiatan ini dianggarkan sebesar Rp. 50.000.00,--

Berdasarkan riset yang telah dilakukan, penulis melihat bahwa Museum R.A Kartini tidak hanya digunakan sebagai tempat untuk memajang benda-benda bersejarah terkait R.A Kartini namun juga sering digunakan untuk penyelenggaraan beberapa even. Seperti yang telah dilaksanakan oleh Dinas Perindustrian Perdagangan Koperasi dan UMKM pada tahun 2016 yang menyelenggarakan berbagai macam even. Even yang diselenggarakan diantaranya adalah lomba batik tulis, batik carnival, batik exhibition, dan sebagainya.

Hal ini menunjukkan bahwa pengelola Museum R.A Kartini sangat terbuka dan ternyata museum juga bisa digunakan sebagai fasilitasi pelaksanaan suatu even. Apalagi saat ini berkembang pula pariwisata MICE (Meeting, Incentive, Conference, Exhibition) di Indonesia. Pelaksanaan even di Pendopo Museum R.A Kartini masih didominasi dengan kegiatan yang berkaitan dengan peringatan hari R.A Kartini. Dominasi ini tidak hanya terkait tingkat kunjungan yang semakin tinggi namun juga kuantitas pelaksanaan even yang diadakan di Museum R.A Kartini. 
Sehingga pada bulan April menjadi high season karena adanya rangkaian pelaksanaan even dengan konsep Kartinian. Kartinian merupakan suatu konsep kegiatan yang diselenggarakan dengan berbagai macam kegiatan yang bertujuan untuk memperingati R.A Kartini. Strategi even dengan konsep kartinian masih digunakan setidaknya sampai tahun 2017 dengan tema Gema Kartini.

Pada tahun 2016 rangkaian kegiatan kartinian diselenggarakan di pendopo Museum R.A Kartini dengan berbagai macam even seperti pameran fotografi, lomba karawitan, pameran objek wisata, dan pameran lukisan. Selain itu even lain yang banyak menarik minat wisatawan adalah Opera the life of Kartini dan kirab Pataka R.A Kartini sebagai bagian dari napak tilas yang rutin diselenggarakan setiap tahun. Kirab Pataka merupakan kegiatan perjalanan bersama-sama warga dengan membawa bendera warna hijau bertuliskan kata-kata mutiara yang pernah diucapkan oleh R.A Kartini. Rute perjalanan kirab Pataka ini adalah dari pendopo Museum R.A Kartini menuju kompleks pemakaman R.A Kartini di Kecamatan Bulu sejauh 17,5 km.

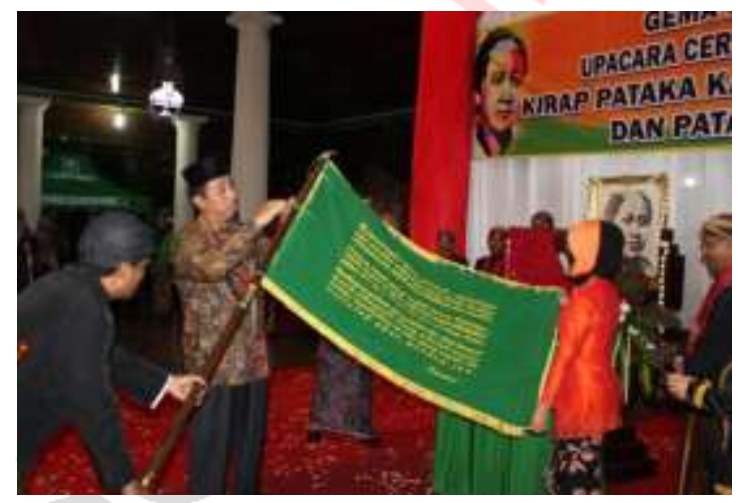

Gambar 2. Penyematan Bendera Pataka oleh Bupati Rembang pada April 2016 Sumber: www.tribratanews.com, diakses 12 Januari 2018
Penyelenggaraan even di pendopo Museum R.A Kartini pada tahun 2017 memiliki konsep acara yang sangat berbeda. Penyelenggara even mampu memberikan nuansa yang berbeda dengan konsep kartian pada beberapa tahun sebelumnya. Penyelenggaraan even di pendopo Museum R.A Kartini pada tahun 2017 berhasil mendatangkan keluarga besar R.A Kartini yang masih hidup dan juga mengundang perwakilan Duta Besar Belanda dari Jakarta. Keluarga besar R.A Kartini yang hadir pada malam tersebut adalah cucu menantu R.A Kartini Sri Bijatini, dua cicit bernama Rukmini dan Samingun Bawadiman, cicit menantu Umiyati, dan dua canggah R.A Kartini yang bernama Joddy Mulya Setya Putra dan Hanif Satrio Rahmansyah.

Melalui jamuan makan malam bersama keluarga R.A Kartini di pendopo Museum R.A Kartini, ada upaya penegasan bahwa Museum R.A Kartini sangat terbuka dan bisa digunakan dalam penyelenggaraan berbagai even. Selain jamuan makan malam dengan keluarga R.A Kartini, berbagai even juga dilaksanakan di pendopo Museum R.A Kartini Rembang seperti Senin Pahingan, Diskusi Budaya Sendon Waton, dan even rutin tahunan Kirab Pataka.

Penyelenggaraan even di tahun 2017 terdapat semacam upaya cukup baik untuk meningkatkan kualitas penyelenggaraan even kartinian. Skala penyelenggarannya tidak hanya bersifat lokalitas namun juga skala nasional dan internasional. Apalagi rangkaian evennya dipusatkan di Museum R.A Kartini Rembang. Secara umum Museum R.A Kartini Rembang bisa memperbaiki kualitas penyelenggaraan even belajar dari model pengelolaan even seperti Museum House of Sampoerna. Metode ini yang oleh beberapa ahli 
dinamakan sebagai bentuk komunikasi pemasaran kepada konsumen.

Ali Hasan (2015) merekomendasikan bentuk-bentuk komunikasi pemasaran yang dapat diterapkan untuk membangun brand image terdiri dari public relations yaitu melalui media penyelenggaraan even seperti even pameran, interactive internet marketing yaitu melalui blog atau website pengunjung. Penggunaan model komunikasi pemasaran semacam ini akan memberi peluang kepada pengunjung untuk menulis dan mengulas pengalamannya setelah mengunjungi House of Sampoerna, demikian juga penggunaan advertising dapat menjadi pemberitaan wartawan pada media cetak setelah melakukan liputan tentang even yang diadakan di House of Sampoerna (Gahari, 2015)

\section{KESIMPULAN DAN REKOMENDASI Kesimpulan}

Berdasarkan analisa yang telah dilakukan dalam penelitian ini maka bisa diambil kesimpulan bahwa:

1. Museum R.A Kartini Rembang memiliki potensi besar dalam menyuplai faktor kesenangan untuk mengisi waktu luang masyarakat (rekreasi);

2. Tingkat kunjungan ke Museum R.A Kartini Rembang masih terendah dibandingkan dengan objek wisata lain di Kabupaten Rembang (data dinbudparpora 2014);

3. Penyelenggaraan even di Museum R.A Kartini memiliki peran besar terhadap peningkatan jumlah kunjungan wisatawan ke museum. Hal ini bisa dilihat dari kontribusi Museum terhadap pendapatan asli daerah yang meningkat sejak tahun 2013 sampai 2016;
4. Sayangnya penyelenggaraan even di Museum R.A Kartini hanya dominan diadakan menjelang perayaan Hari Kartini pada bulan April setiap tahun. Sehingga meskipun meningkat kontribusinya terhadap PAD (Pendapatan Asli Daerah), nilai kontribusinya sangat kecil dan tidak sebanding dengan biaya perawatan, honorarium, dan jenis pembiayaan lainnya.

\section{Rekomendasi}

Berdasarkan hasil penelitian yang telah dilakukan, maka terdapat beberapa rekomen-dasi yang perlu dipertimbangkan oleh stakeholders khususnya pemerintah Kabupaten Rembang melalui Dinas Kebudayaan dan Pariwisata:

1. Meningkatkan peran museum sebagai pusat pengetahuan, pendidikan, dan rekreasi salah satunya melalui penyelenggaraan even di Museum R.A Kartini secara rutin;

2. Penyelenggaraan even di Museum R.A Kartini jangan sampai hanya berfokus pada momen kartinian. Hal ini bisa dilakukan dengan meluaskan dan meningkatkan kerja sama dengan berbagai pihak atau mitra, termasuk mitra luar negeri. Mengingat R.A Kartini tidak hanya dikenal dan diingat oleh masyarakat lokal Rembang dan sekitarnya, namun juga masyarakat nasional dan internasional. Selain untuk meningkatkan kualitas brand image hal ini juga akan berpengaruh positif terhadap tingkat kunjungan ke Museum R.A Kartini.

3. Meningkatkan kualitas komunikasi pemasaran untuk membangun dan menjaga brand image Museum R.A Kartini Rembang. 
DAFTAR PUSTAKA

Ali Hasan. 2015. Tourism Marketing. Yogyakarta: Center for Academic Publishing Service.

Ambrose, Timothy dan Paine, Crispin. 2012. Museum Basic. Edisi 3. Abingdon: Routledge.

Amir Sutarga, 1998. Pedoman Penyelenggaraan dan Pengelolaan Museum. Jakarta. Departemen Pendidikan dan Kebudayaan Direktorat Jenderal Kebudayaan.

Barron, P., \& Leask, A. 2017. Visitor engagement at museums: Generation Y and "Lates" events at the National Museum of Scotland. Museum Management and Curatorship, 32(5), 473-490.

Camarero, C. 2009. Improving Museums Performance Through Custodial, Sales, and Cus-tomer Orientations. Nonprofit and Voluntary Sector Quarterly, 38(5), 846-868.

Camarero, C., \& Garrido, M. J. 2012. Fostering Innovation in Cultural Contexts: Market Orientation, Service Orientation, and Innovations in Museums. Journal of Service Research, 15(1), 39-58.

Cole, D. 2008. Museum marketing as a tool for survival and creativity: The mining museum perspective. Museum Management and Curatorship, 23(2), 177-192.

ICOM. 2004. Running a Museum: A Practical Handbook. Paris. ICOM

Leksono, Sigit Eko. 2017. Analisis Permintaan Wana Wisata Kartini Mantingan Kabupaten Rembang Jawa Tengah (Skripsi Universitas Diponegoro). Semarang

Lindqvist, K. 2012. Museum finances: challenges beyond economic crises.
Museum Management and

Curatorship, 27(1), 1-15.

Nielsen, J. K. 2017. Museum communication and storytelling: articulating understandings within the museum structure. Museum Management and Curatorship, 32(5), 440-455.

Manzilati, Asfi. 2017. Metodologi Penelitian Kualitatif: Paradigma, Metode, dan Aplikasi. Malang: Universitas Brawijaya Press.

Gahari, R. 2015. Bentuk-Bentuk Komunikasi Pemasaran Museum House Of Sampoerna Dalam Membangun Brand Image. Commonline Departemen Komunikasi, 4(1), 341-356.

Pemkab Rembang (RKPD). 2014. Rencana Kerja Pemerintah Daerah [RKPD] Kabupaten Rembang Tahun 2015.

Pencarelli, T., Cerquetti, M., \& Splendiani, S. 2016. The Sustainable Management of Museums: Tourism and Hospitality Management, 22(1), 29-46.

Subhiksu, Ida Bagus Kade dan Gusti Bagus Rai Utama. 2018. Daya Tarik Wisata Museum Sejarah Di Ubud Bali. Sleman. Deepublish

Stylianou-Lambert, T., Boukas, N., \& Christodoulou-Yerali, M. 2014. Museums and cultural sustainability: stakeholders, forces, and cultural policies. International Journal of Cultural Policy, 20(5), 566-587.

Unesco dan Ifescco. 2012. Role of Museums in Education and Cultural Tourism Development: Policy Brief. Kyiv: Ukrainian Committee of Icom.

Yusuf, Musri A. 2014. Metode Penelitian: Kuantitatif, Kualitatif, dan 
Penelitian Gabungan (Edisi

Pertama). Jakarta: Kencana.

https://www.tribratanews.com/polwan-

polres-rembang-ikut-meriahkan-

gema-kartini-2016/. Diakses tanggal

12 Januari 2018.

http://mataairradio.com/berita-

top/pengunjung-museum-kartini-

meningkat-setoran-bertambah.

Diakses pada 11 Januari 2018.

https://www.jawapos.com/radarkudus/read/

2017/07/27/4067/sektor-pariwisataberkembang-pesat. Diakses pada 11 Januari 2018. 